\title{
Academic literacies twenty years on: a community-sourced literature review
}

\section{John Hilsdon}

University of Plymouth, UK

\section{Cathy Malone}

Sheffield Hallam University, UK

\section{Alicja Syska}

University of Plymouth, UK

\begin{abstract}
In 1998, the paper 'Student writing in higher education: an academic literacies approach' by Mary Lea and Brian Street reinvigorated debate concerning 'what it means to be academically literate' (1998, p.158). It proposed a new way of examining how students learn at university and introduced the term 'academic literacies'. Subsequently, a body of literature has emerged reflecting the significant theoretical and practical impact Lea and Street's paper has had on a range of academic and professional fields. This literature review covers articles selected by colleagues in our professional communities of the Association for Learning Development in Higher Education (ALDinHE), BALEAP the global forum for English for Academic Purposes (EAP) professionals, and the European Association of Teachers of Academic Writing (EATAW). As a community-sourced literature review, this text brings together reviews of wide range of texts and a diverse range of voices reflecting a multiplicity of perspectives and understandings of academic literacies. We have organised the material according to the themes: Modality, Identity, Focus on text, Implications for research, and Implications for practice. We conclude with observations relevant to these themes, which we hope will stimulate further debate, research and professional collaborations between our members and subscribers.
\end{abstract}

Keywords: academic literacies; modality; identity; academic writing; knowledge making. 


\section{Introduction}

Mary Lea and Brian Street published their paper 'Student writing in higher education: an academic literacies approach' in 1998. This special edition of the Journal of Learning Development in Higher Education (JLDHE) takes stock of developments some twenty years on. We have collated this community-sourced review of some of the literature associated with the field that has become known as 'academic literacies' using contributions from 17 colleagues (listed below and marked in the text in bold font) from three professional bodies: the Association for Learning Development in Higher Education (ALDinHE), BALEAP the global forum for EAP professionals, and the European Association of Teachers of Academic Writing (EATAW). Contributors were invited to submit critical reviews of texts listed in our call for papers, or to review alternative, related texts, which they believed would be of interest. The results, synthesised here, represent responses from our three practitioner communities to an acknowledged seminal paper and to the debates and further literature it generated and continues to generate. While a systematic literature review aims for a comprehensive analysis of the literature on a topic in order to identify key findings and research gaps, the purpose of this review is slightly different. As one of the roles of HE is to further the conversation a society has with itself (Bernstein, 2000, p.xx), so our objective here is to further the conversations within and between our learning communities that have arisen from Lea and Street's paper and the responses to it in terms of research and pedagogy.

\section{A collaborative writing process}

The community sourcing of material for this paper was an attempt to reflect the views and highlight concerns of our three (related yet distinct) professional bodies and areas of academic practice. In selecting contributions, identifying key themes and synthesising content, we were mindful of the need to balance our responsibilities to our co-contributors with our aim to produce a coherent text. We conducted numerous online conversations and shared many drafts as we juggled these obligations and shaped this paper - a process that was very much assisted by the affordances of digital writing technologies. Our exploration of fragmentation and reconstruction in producing a multi-voiced text through a layered collaborative writing process reflects a (still relatively new) form of academic authorship where precise attribution is difficult. This process of attempting to write within 
boundaries which we simultaneously seek to disrupt (Lillis and Tuck, 2016, p.39) was paradoxically both liberating and constraining. We are conscious that with the commodification of student academic writing (McKenna and Hughes, 2013, p.21) and the discourses of ownership and legalistic attribution, the exploratory space we were afforded, in which we could share and develop ideas, is rarely on offer to our students. This is turn aptly demonstrates how academic writing conventions reflexively constrain or expand the opportunities for meaning making, an issue at the heart of academic literacies research. To place this review in historical context, Lea and Street's 1998 paper emerged at a time of 'massification' in UK HE. Expansion in the recruitment of students from 'non-traditional' backgrounds and from overseas during the last decades of the twentieth and the first decade of the twenty first century was accompanied by the creation of new academic roles designed to provide 'study skills' and support for those for whom English was not their first language. Despite the policy to invite such non-traditional students into $\mathrm{HE}$, they were often described pejoratively, typically suggesting that their writing abilities would limit their academic progression or that academic standards would fall as a result of their presence (Scott, 1995; Haggis, 2006; Smith, 2007; Lea, 2015).

A number of professional bodies emerged in response to this massification: BALEAP formed in 1989 building upon a range of precursory collaborations that had begun in the 1970s; EATAW was formed in 1999; the Learning Development in Higher Education Network (LDHEN) in 2003; and the Association for Learning Development in Higher Education was established in 2008 (Hilsdon, 2011). While many of those recruited to study skills and student support posts quickly became critical of the limitations of their roles and the unrealistic expectations placed upon them, a widespread response to massification focused on the 'problem' of student writing. Mastery of academic discourse was seen as central to student success, but at the same time debate was constrained by prevailing simplistic conceptions of literacy. Against this backdrop of upheaval and role changes for students, staff and institutions, Lea and Street's theoretically informed and research-driven approach to understanding how students learn to write at university made a significant impact. Discussions within these professional groups sparked interest in the academic literacies perspective as an alternative to the prevailing 'deficit' conceptualisation of nontraditional students (Mann, 2001; Haggis, 2006). It is worth briefly summarising here some of the key themes in Lea and Street's 1998 text. 


\section{Learning to write in HE: context, practices, power and identity}

Acknowledging the difficulties of the endeavour of learning to write at university, Lea and Street set out 'to develop a more complex account of what it means to become academically literate' (1998, p.158). They map contestations between different stakeholders:

[l]t is important to realise that meanings are contested among different parties involved: institutions, staff and students. Viewing literacy from a cultural and social practices approach (rather than in terms of educational judgements about good and bad writing) and approaching meanings as contested can give us insights into the nature of academic literacy in particular and academic learning in general (1998, p.158).

Their ethnographic, practices-based approach focuses on the student experience of learning to write and, in doing so, validates and values learners' understandings from their perspectives and contexts. This helps to show 'the importance of issues of identity and the institutional relationships of power and authority that surround, and are embedded within, diverse student writing practices across the university' (1998, p.157). The dissonances and tensions between different stakeholders and institutional perspectives of what it means to become academically literate can then become rich material for discussion and for developing academic literacy. However, Lea and Street's focus on '[a]cademic literacy practices - reading and writing within disciplines ... [as the] central processes through which students learn new subjects and develop their knowledge about new areas of study' (1998, p.157) has itself been seen as overly restricted to written text rather than visual, conversational, and other modes of communication (see Goodfellow, 2005; Archer, 2006).

Lea and Street's stress on the way literacy practices enact power relations, and impact on identity issues for students and others, acknowledges universities as sites of 'discourse and power' that privilege specific relations and ways of knowing (1998, p.159). This critical, socio-political framing of academic writing research and pedagogy has since evoked a significant response from researchers, theoreticians and practitioners working in universities, as evidenced by the quantity and breadth of the literature referred to below. 
Lea and Street's academic literacies approach critiques what they term 'study skills' and 'socialisation' models of writing instruction in HE:

[T]he models are not mutually exclusive and we would not want to view them in a simple linear time dimension whereby one model supersedes or replaces the insights provided by the other. . . The academic literacies model . . . incorporates both of the other models into a more encompassing understanding of the nature of student writing within institutional practices, power relations and identities. . . We take a hierarchical view of the relationship between the three models, privileging the ‘academic literacies' approach (1998, p.158).

Some advocates of linguistically informed approaches to writing development (Coffin and Donoghue, 2012; Tribble and Wingate, 2013), have taken issue with this view. In the twenty-one years since its publication the paper itself opened up a rich vein of research and response. One reason for this is that it reframed the way academic writing is discussed and opened up new ways of analysing how students find their disciplinary voices. The landscape in which students study and write essays has evolved in multiple ways, influencing the 'possibilities of selfhood' (Ivanič, 1998) for student writers. Researchers have documented the accompanying changes in attitudes and values amongst teaching staff, which have not always been positive, and reported on the pressure on teaching staff (Fuller et al., 2004; Wingate, 2006; Riddell et al., 2007; Gourlay, 2009; Ashworth et al., 2010; Cameron and Billington, 2015; Office of Fair Access, 2017). These pressures in turn have contributed to observed changes in student identity (Eurydice, 2014).

Reflecting how the wide range of responses to Lea and Street's 1998 paper have resonated with our professional communities, we have grouped contributions to this synthesis of reviews into the following themes:

1. Modality: discussions relating to modes of study in $\mathrm{HE}$; for example, the development of e-learning.

2. Identity: processes and practices in identity formation.

3. Focus on text: discussions of analytical approaches such as genre and systemic functional linguistics and their relationship to writing development. 
4. Implications for research: theoretical framing and investigation of issues associated with the development of academic writing.

5. Implications for practice: in pedagogy and in supporting learning.

\section{Modality}

Several of the texts reviewed by our participants develop ideas about modes of study, expression and the construction of meaning, such as in speech, performance and ' $e$ learning'. Some see a contradiction in the early work on academic literacies in that, despite the critical and transformational purposes espoused, a primary focus on traditional forms of written expression is implied and may work to reinforce the privileging of this mode of academic practice. Lillis and Scott (2007), for example, call for a critical approach to epistemology as a fundamental underpinning of academic literacies work, feeding into pedagogy - teaching, learning and assessment practices - and strategies for course design.

In her review of Arlene Archer's 2006 paper, 'A multimodal approach to academic "literacies": Problematising the visual/verbal divide', Christina Howell-Richardson points to disciplinary meaning-making as constructed in multi-modal texts and how these 'different semiotic dimensions of representation' (2006, p.450) both sit alongside and differ from traditional academic writing. Drawing on Kress and Van Leuwen's (2001) theory of multi-modal discourse, Archer's purpose is to enquire into ways in which first year Engineering students from non-traditional backgrounds use visual and verbal modalities to express meanings. The data for Archer's study include written text and posters. HowellRichardson reviewed this text because it highlights the ways in which students responded to the different affordances of visual images and writing for various communicative purposes. As she states:

[Archer's] work is primarily focused on the experiences of home-based EAL students entering a South African University at a time of a newly introduced widening participation policy, which resonates with my own questions related to the challenges of teaching highly diverse groups. ... [T] he paper has value in unambiguously setting out the original thinking . . . [and] the potential of 
multimodality to circumvent the cultural and linguistic hegemony identified by Lea and Street's seminal (1998) paper.

Howell-Richardson feels that Archer's discussion of different functional conceptions of literacy is especially interesting. Citing Archer's careful teasing out of attributes of literacy and the need for recognition of differences in usage and potential across modalities, she argues:

[A]lthough this publication dates from a time before digital technologies became universal, Archer raises questions about use of multi-modality in pedagogy and assessment that are relevant to current debates on inclusive learning environments and the reframing of the curriculum to represent a wider range of cultures and cultural histories.

The enduring impact of this paper is not to 'posit multimodality as an alternative way of inducting students into academic writing practices' (2006, p.449); instead, Archer problematises our over-reliance in Higher Education on students' writing to demonstrate their discursive competences. She also seeks to highlight the work of theorists such as Gunther Kress - on how values are embedded in discourses, and Norman Fairclough - on the role of discourse in social change. These ideas, used alongside the examples of student work she draws upon, help her to illustrate that 'language, power and modalities are inextricably intertwined' (2006, p.459). Thus, she argues for a pedagogy that both accounts for diversity and promotes unity by making multimodality part of a theory of communication. As she concludes, 'a multimodal approach to teaching academic literacy practices could enable a curriculum design which draws on the full range of students' semiotic resources and may also help to create less structured curriculum spaces' (2006, p.460).

The rise of online learning environments and proliferation of new modes for constructing and expressing knowledge, including via online communications and social media, prompted Louise Stringer to review a paper by Robin Goodfellow, 'Academic literacies and e-learning: A critical approach to writing in the online university'. Although now 13 years old, this text remains important since, increasingly, students in HE need to navigate 
unfamiliar communication situations with tutors and peers whom they have not physically met.

Adopting an academic literacies perspective, Goodfellow evaluates master's students' experiences of engagement with an online writing resource to support distance learners' 'critical awareness of the writing practices on the programme' (2005, p.481). He highlights problems for non-traditional and distance/online students related to the centrality of writing and embedded issues of power associated with control of dominant discourses, which disadvantage some students. Focusing on the (non-traditional) student experience of learning to write at university demonstrates the differences between socialisation approaches to writing, which prioritise immersion in the literacy practices of the discipline, and what he terms 'more humanistic concerns with self-discovery, voice, and class, ethnic and personal identities' (2005, p.482). He points out that 'disciplinary requirements for writing are by no means transparent, and the ways in which subject-specialist teachers attempt to articulate them may be mystifying to novice writers' (2005, p.482). Furthermore, the increasingly modular and inter-disciplinary character of university study activities means students must act in overlapping domains of communication - and this is amplified by the uses of online HE environments. Despite general calls for students to become critical thinkers, policy and management's drive to '[position] communication as a generic skill obscures the context-dependent dimension of language . . . and works against engaging learners in a critique of literacy practices in university classrooms' $(2005$, p.482). Developing a critique of both socialisation and skills-based models of developing writing, Goodfellow reminds us of ideological as well as pedagogic dimensions 'concerned with the way that writing is used to construct relations of power and authority' (2005, p.482) that are likely to disadvantage certain students disproportionately. He argues that 'we need to support students in developing critical awareness of writing practices . . . in online . . . as in other arenas of academic meaning-making' (2005, p.482); we need 'a pedagogy for academic literacies [that] draws attention to the plurality of communication practices implicated in what is generally termed "academic writing", foregrounding the need to engage students in a critique of the writing practices they encounter' (2005, p.482). It is not sufficient to demystify existing practices; rather, Goodfellow shares Street's view that students need to be supported in contesting conventions, 'producing a genuinely empowered subject, i.e. neither the "cynic nor the 'good' student who 'does like we do'"' (Goodfellow, 2005, p.483). This means encouraging students to 'reflect critically on their 
own and others' learning and its relation to the norms and goals that are embedded in the discourses of the ... classroom' (p.483).

Goodfellow concludes by calling for greater attention to the construction and use of text in online environments as a helpful way to shed light on the role of writing as discourse in teaching and learning more generally, and a way to promote an academic literacies informed pedagogy. The 'discourse-analytic' (2005, p.486) framework employed in his analysis of student texts still provides a good example of how others could frame studies where students are encouraged to develop critical awareness of how language is used in the academy.

Theresa Lillis and Jackie Tuck's book chapter 'Academic Literacies: A critical lens on writing and reading in the academy' (2016) also raises key questions about modality. It was chosen by Jessica Garska, an EAP practitioner, because it provides a powerful, historical outline of the field and suggests ways to encourage dialogue between researchers in academic literacies and critical EAP. Traditional academic discourse and practices are shown to be contested, saturated with identity, power and culture. Key differences between the fields of academic literacies and EAP are emphasised, contrasting a focus on producer versus on text; 'English' as contested in nature and status versus a standard English as the target and focus; encouragement of diversity of knowledge and experience versus a voice-expert dichotomy; and a transformative versus a normative focus. Lillis and Tuck also identify convergences between academic literacies and critical EAP, allowing for rethinking the categories and concepts of producers, trajectories, linguistic and non-linguistic semiotic resources, writing as a social activity, transformative pedagogy, and creative risk-taking in the academy.

Garska explains that this text played a role in her questioning of theoretical perspectives and pedagogical approaches:

The [chapter] by Lillis and Tuck (2016) was the first that I have read, which clearly and distinctly articulated the two fields as separate, yet also identified similarities and areas for engagement. . . Lillis and Tuck (2016) explicitly state what the field of academic literacies is, where it comes from, and how it is both distinct from and 
similar to EAP... . It can also provide a starting point for engagement with similar theories in different fields [such as] translanguaging and critical EAP.

Lillis and Tuck set out the case for academics from all traditions to engage with research emerging from both critical EAP and academic literacies questioning existing practices in teaching, assessment and research. Critical, questioning approaches and a transformational agenda, they argue, should not be seen as a distraction from core business but as ultimately practical. They note that criticism of academic literacies has sometimes implied it does not help to 'raise students' awareness of valued academic genres and to support them to present "polished" work' (2016, p.36). The authors rebut this argument with examples such as how academic literacies approaches to marking and assessment practices are complimentary to work aimed at enhancing non-traditional student achievements. Reversing questions on the 'problem' of student writing, so that they are redirected onto how academic and institutional practices bear on student meaning-making in various modes, helps identify where sustainable improvements can be made. They conclude that "criticality is key to any pragmatism centred on ... desires for meaning-making as well as on academic success' and in the service of 'developing richer understandings of knowledge making in the contemporary world' (2016, p.37).

The three publications referred to in this section share a concern to direct attention away from a definition of literacy as confined to the construction, by students, of written texts that conform to traditional academic conventions. Rather, they emphasise the need to redefine literacies in multi-modal terms where knowledge is constructed, expressed, contested, and assessed by all members of the academic community. In this way, they demonstrate the enduring power of the academic literacies perspective, as crystallised in Lea and Street's 1998 paper, to provide a generative framework for discussions about practice in pedagogy, research and policymaking.

\section{Identity}

Conflicts and tensions in the academic writing environment discussed by Lea and Street (1998) influence the ways in which student writers develop their writer identities. In this section, we bring together four papers that in their own distinctive ways respond to the challenges facing students in the academic writing context and encourage reflection on our 
current strategies of meeting their increasingly diverse needs. The four articles include:

'Writing and being written: Issues of identity across timescales' (Burgess and Ivanič, 2010) reviewed by Aileen Hanrahan; 'Pedagogies for diversity: retaining critical challenge amidst fears of "dumbing down"' (Haggis, 2006) reviewed by John Hilsdon; "Fail better": Reconsidering the role of struggle and failure in academic writing development in higher education' (French, 2016) reviewed by Cathy Malone, and 'Threshold practices: becoming a student through academic literacies' (Gourlay, 2009) reviewed by Peter Levrai.

In the same year as Lea and Street's exposition on academic literacies, Roz Ivanič (1998) pointedly argued that writing is an act of identity and this academic writing identity has four aspects: socially available possibilities of selfhood, the autobiographical self of the writer, the discoursal self, and the authorial self. Her theories of identity were further developed by Burgess and Ivanič (2010), where the authors added one more dimension of writer identity (the 'perceived writer') and emphasised that identity changes over time, is multifaceted, and may be unconscious or conscious in its development. Student writers may participate in multiple, and sometimes contradictory, discourses that shape their sense of self, depending on the social spaces they inhabit, which then has an impact on the multidimensional selfhood they bring into these spaces. These change according to different timescales (Wortham, 2003) - from sociocultural timescales counted in decades or even centuries (e.g. gender or class identity) through ontogenetic and mesolevel timescales that encompass one's lifespan (e.g. life choices or phases) to microgenetic timescales that concern the lived experience of the moment (e.g. the act of writing itself). All these identities that persist on different timescales are interrelated and deeply agentive - not only are they equally capable of shaping an act of writing, but are also profoundly affected by the writing process itself. Importantly, the construction of writer identity is highly sensitive to the changing times and discourses (Burgess and Ivanič, 2010).

Since Lea and Street's article over two decades ago, the nature of the conflicts and tensions in $\mathrm{HE}$ has changed considerably, and with these shifts so too have changed students' identity building mechanisms. The altered conditions in UK HE have been particularly effectively pointed out by Tamsin Haggis in her much-quoted article 'Pedagogies for diversity: retaining critical challenge amidst fears of "dumbing down"' (2006). Haggis drew attention to the effects of post-1992 neoliberal reforms including massification, marketisation, and a focus on producing skilled graduates for the labour 
market. These reforms produced new initiatives, such as widening participation, which, as John Hilsdon notes in his review, caused concerns expressed in the media about 'falling standards' in HE, alongside internal concerns of some academics, which Haggis terms 'defensive cynicism', about students who are 'seen to be incapable of coping with the critical challenges of conventional higher education' (2006, p.523). As she explains, '[t]his response appears to equate widening participation with an inevitable abandonment of certain key elements of higher education assumptions and values in relation to learning' (p.523). Rather than seeing this situation in terms of 'falling standards', however, Haggis suggested instead that it was a challenge to HE 'to transform potentially alienating types of exposure to propositional knowledge (Mann, 2001) into richer kinds of engagement, in order that a much wider range of students might gain access to conventional and established forms of knowledge and power' (Haggis, 2006, p.522; emphasis added). She also questioned the assumption that what is needed is more attention either to learning approaches or styles, or to the provision of more generic study skills support to 'at risk' students. In any case, she suggests, given the very high increase in numbers of students in HE characterised as “"mature”, "disadvantaged", "non-traditional”, "overseas", and '[p]erceived as being "weaker” in terms of educational experience and/or ability' (p.522), it would be practically impossible to provide such support. Instead, she argues, those supporting learning should offer 'embedded, subject-specific exploration of different types of disciplinary process' (p.533) and that academics should articulate more clearly what they believe, wish to share through their teaching, and what they expect students to do. In this respect, Amanda French (2016) responds to Lea and Street's (1998) academic literacies approach by calling on educators to resist 'the obsession with standards and performativity' and instead help students 'to understand that developing into confident academic writers is not a straightforward, linear or automatic process; rather it inevitably involves struggle, conflict and feelings of uncertainty, inauthenticity, marginalisation, exclusion and occasionally, failure' (French, 2016, p.409). These struggles and conflicts have a significant impact on student writer identity. Citing Biggs and Tang (2011), French offers a 'metacognitive approach to HE writing development which encourages students to consider not only what . . but how and why they need to write in particular ways in higher education' (2016, p.409; emphasis in original). She provides a critique of three common approaches to writing development in UK HE (Writing Centres, bolt-on Study Skills modules, and Writing across Curriculum and Writing in Disciplines approaches) and then describes working with subject specialists embedding teaching of academic writing at a 
disciplinary level. As Cathy Malone points out in her review, French acknowledges that the process of learning to write for some is 'complex, painful and erratic' (p.409), and this is used to counterpoint the simplicity of institutional models of writing where student development is presented as linear and automatic. French draws on Street's work to critique university discourse on academic writing that presents writing as 'a decontextualised set of skills', which, once learnt, 'can be applied . . . universally, without reference to any ideological or cultural values' (French 2016, p.409-410). French reviews these models of learning and the conceptions of writing in a way that rejects identity implications of personal failure and refocuses attention on the institutional failure to meet the increasingly diverse writing development needs that many students . . . might present' (2016, p.410). This attention shift from personal to the institution aligns with the ambition of the original academic literacies work and has been reaffirmed more recently by Lea, who suggests the 'need to reclaim the institutional perspective that was inherent in some of the early work in the field of academic literacies' (Lea 2016, p.88). It is also an argument that is still current across the sector.

French sums up major trends in how writing is supported at university while foregrounding the student experience and acknowledging the difficulty and distress of transition. According to Malone, this methodological focus offers an antidote to the rampant performativity of UK HE and the mechanistic nature of 'you said - we did' service evaluation. It models careful reflection on actual student experience, recasting failure as opportunity in a way that opens up 'an alternative discourse of "generative failure"' (Harris, 2014; cited French, 2016, p.414). Indeed, in the previously mentioned article, Haggis already suggested that it is impossible to succeed in meeting the needs of the range of students now coming into higher education, both in terms of the extent of this diversity and in terms of available resources' (2006, p.522). Instead, she calls for 'a change of perspective' from the deficit approach to students and refocuses our attention on the principle of treating students as ends in themselves (Mann, 2001). As John Hilsdon put it in his review of Haggis's paper, the interpretation of academic literacies it points to is one that does not simply call for students to (be helped to) learn the language and discourse practices of their subject (important though that is), but to be treated respectfully as participants in the academic community, even as they enter it - somewhat as in the idea of legitimate participation promoted by Lave and Wenger (1991) - on an inward trajectory, so that students might feel encouraged and supported not just to acquire relevant practices of 
the academy but to comment upon them, critique, and even improve them. Reading Haggis's paper is a helpful way into thinking about Sarah Mann's (2001) idea that developing learning in a modern, accessible $\mathrm{HE}$ environment requires not transactional and transmission pedagogies but an orientation where students are treated as ends in themselves - with all their rich linguistic and cultural variety being acknowledged in the curriculum and by academic practices. In other words, rather than being objectified as 'learners' to be acted upon, students are to be actively involved in all aspects of HE.

This idea of the development of communities of practice (Wenger, 1998) is particularly important when considering how students transition into university, which can be not only an emotionally challenging process that changes novice newcomers into more confident members of the university, but also one that can have a dramatic impact on student identity, something examined by Lesley Gourlay in 'Threshold practices: becoming a student through academic literacies' (2009). As Peter Levrai notes in his review of the article, what particularly stands out in this paper is the critique of the communities of practice when it comes to higher education, particularly in terms of the limited interactions between tutor and student, which problematise the idea of 'mutual engagement' where the novice can learn working alongside the expert. Levrai concludes that this is an area where EAP can play an important role, helping the student through the academic writing process and offering that mutual engagement through formative feedback. It is also an area where collaborative writing assignments can help students navigate new ways of writing, providing a social as well as academic support network, so they can pass through threshold practices together.

While questioning the applicability of the concept of communities of practice to higher education contexts, Gourlay favours the concept of 'liminality', which recognises that students need to engage in threshold practices during their transition and that during this process they may experience emotional destabilisation, uncertainty and ambiguity. Her study shows how writing can be an important aspect of students transitioning into believing they belong at university, which links back to the idea of selfhood as theorised by Burgess and Ivanič (2010). Writing can be a challenging process, where students may be unsure of what is expected of them, but can also provide a turning point into belonging when receiving positive feedback or a successful grade. Gourlay argues that 'a recognition of academic literacies as threshold practices could open up discussion of tacit practices' with 
regard to 'how knowledge is textually constructed' (2009, p.189; emphasis in original). The approach could also help students to accept that uncertainty, struggles and even failures are 'a normal part of the academic process, as opposed to indicating a deficit' (p.189), thus limiting the potentially detrimental impact of failure on student writer identity.

Academic writing has always been a key skill for entry into 'the academy'; now, however, in a digital era, the question over academic writing and its relationship to professional writing contexts has further highlighted Lea and Street's (1998) observation that there was no consensus as to what academic writing was then, or what it is now. Recently that argument has changed into an argument about what constitutes 'academic excellence' and who should hold authority to maintain such a concept (Riddell et al., 2007; Shaw, 2009). As Aileen Hanrahan points out in her review of Burgess and Ivanič (2010), with the essay serving as one of the main points of contact with academic staff, in terms of working on drafting, marking and giving feedback on the writing, the essay becomes the cornerstone of where student identity-building through contestation becomes manifest. Contestation may take the form of engagement with feedback and marking results; with issues about accessing teaching support regarding a particular assignment; or how the reader, in this case an academic, perceives what the writer is trying to achieve in the essay and how that should be judged (e.g. as worthy of academic excellence; see Riddell et al., 2007; Kinder and Elander, 2012).

In this way, Hanrahan compellingly reasons, the essay might be conceptualised as a 'site of conflict', which influences the interactions between the student writer and their intention of becoming a member (or not) of the academy - belonging to the traditionally established community of practice. As she continues, this form of analysis presents a particularly insightful perspective on dyslexia, as a particular community of practice (Gourlay, 2009), and other forms of disability/learning disability. For example, Burgess and Ivanič's (2010) model of identity and changes in identity over time might be applied in future research to increase understanding of changes in the conflicts and tensions in how dyslexia and other disabilities/learning disabilities are conceptualised, and how these changes influence identity-building for specific communities.

Application of reasonable adjustments are known to be haphazard (DSAC, 2015), which translates into essay writing and marking being a site of conflict for many learning-disabled 
students. In many of the research studies cited above they are shown to be contested, which needs further analysis in case studies. Hanrahan demonstrates that conceptualisations of dyslexia, learning disability, disability and reasonable adjustments amongst various stakeholders, and their relationship to identity-building as expressed in essay writing, would benefit from using the Burgess and Ivanič (2010) model. Currently, there is a lack of research on dyslexia in higher education from an academic literacies perspective (Mortimore and Crozier, 2006; Morken and Helland, 2013; Pino and Mortari, 2014; Cameron and Billington, 2015), and more specifically, on dyslexia and identitybuilding mechanisms in academic writing across various sites of conflict.

The authors of the four texts reviewed in this section agree that when it comes to responding to the challenges to student identity as writers, educators should strive for some form of, in Haggis's words, 'richer kinds of engagement' (2006, p.522). This is contrasted, in John Hilsdon's review, with the still all too common and often alienating student experiences of sitting in lecture theatres not really knowing how doing so will help in producing a piece of work - an essay usually - to demonstrate learning, nor how such activities relate to the 'real world' and what they need to learn about it in order to participate and be empowered in it. We should thus promote activities that involve students in meaningful conversations with academics and each other about how teaching and learning are achieved in the university, both traditionally and now, under new 'mass' conditions and with new technologies. The focus of educators must be on the student experience of learning to write at university while acknowledging the multifaceted, painful, and often messy ways in which this experience influences, and is influenced by, student identity.

\section{Focus on text}

Three papers reviewed in this section consider academic literacies in relation to more linguistically informed approaches to writing development. Britt Amell reviews the 2009 article by Russell, Lea, Parker, Street and Donahue, which uses genre to compare academic literacies and writing across the curriculum, unpacking academic literacies through detailed rationale and historical contextualisation. Alicja Syska reviews Wingate and Tribble's (2012) article comparing English for Academic Purposes and academic literacies writing pedagogies, with the aim of synthesising the best of both. Finally, lan 
Johnson reviews Coffin and Donohue's (2012) paper comparing academic literacies and systemic functional linguistics. The latter two papers form a critical response to the original article and represent a keener concern with classroom practice.

The article "Exploring notions of genre in "academic literacies" and "writing across the curriculum": Approaches across countries and contexts' (2009) emerged from an international symposium on genre, which included Mary Lea and Brian Street. As Britt Amell notes, using genre as a focus the article compares two approaches to teaching writing in higher education that emerged in the US and the UK: Writing across the Curriculum (WAC) and academic literacies respectively. They contrast historical origins, institutional positions, theory and research about genre and pedagogy using genre to identify commonalities, intersection and difference. While each approach emerged from specific educational contexts, there are significant similarities: both 'took their impetus from widening participation' (2009, p.396) and 'both are oppositional, attempting to reform higher education and make it more open ... [using] writing/literacy to resist deeply entrenched attitudes about writing and about students and disciplines' (2009, p.396). The historical origins of academic literacies are mapped out in a detailed research narrative that clarifies some of its distinctive features. Street's ideological model of literacy, first explored in 1984, is identified as key. This understanding of literacy

highlights the contextual and social nature of literacy practices, and the relationships of power and authority which are implicit in any literacy event. Literacy, then, is not something that once acquired can be effortlessly applied to any context requiring mastery of the written word (Russel et al., 2009, p.399).

Similarly, a connection is made with the ethnographic approach to research evident in Lea's work, specifically her focus on the micro-level of practice applied to observing students learning to write through acculturation to norms and conventions. Both Lea and Street are concerned with exploring how issues of power and identity are played out through academic writing at university.

Amell notes the value of genre as a lens through which to explore academic literacies and clarify it as a theoretical frame, evident in the following explanation offered by Russell et al.: 
Issues of genre are central to the three models of student writing outlined [in the paper] (skills, socialisation, and academic literacies). Each of these models is implicitly associated with a different orientation to the notion of genre. In terms of study skills, genre would be conceptualised as primarily in relation to surface features and form; academic socialisation would be associated with the conceptualisation of genre in terms of established disciplinary norms for communication, given primarily by the texts written by academics within the disciplinary community. The empirically grounded academic literacies perspective is aligned with a view of genre as social practice, rather than genre knowledge in terms of disciplinary communication per se (2009, p.405).

An academic literacies approach highlights the extent of genre variation students are faced with and the 'genre switching' (Scalone and Street, 2006) that they need to demonstrate. The ethnographic research roots of academic literacies are evident in an analysis that focuses on 'the different interpretations and understandings of genres of the participants of any particular writing encounter at university' (2009, p.406). Similarly, this focus on unpacking 'micro-social practices, such as "gaps" between student and teacher perceptions of particular writing activities' (2009, p.414) aligns with this research orientation and a social-practices model of genre, which presents meaning as emerging from the 'relationship between the creation of texts and their associated practices in any particular context ... [which] vary across disciplines, subjects, fields of study and text types' (p.406). This results in quite a different approach to supporting student writing, which goes beyond general disciplinary concerns or subject focus. Applying the principles of academic literacies to genre involves looking at the 'level of epistemology, authority and contestation over knowledge, rather than at the level of technical skill, surface linguistic competence and cultural assimilation' (2009, p.400). In practical terms, such an approach implies a more ambitious role for tutors than to simply make disciplinary expectations explicit to students.

As well as clarifying the theoretical positioning of academic literacies, the authors also acknowledge a major criticism that, although practitioner-led, academic literacies tended at this time to be more focused on theory and research than practical applications. This increasing concern with practice became evident in 2012, when two papers were 
published critically comparing academic literacies to English for Academic Purposes (EAP) and Systemic Functional Linguistics (SFL). In 'The best of both worlds? Towards an English for Academic Purposes/academic literacies writing pedagogy', Ursula Wingate and Christopher Tribble (2012) critically reviewed two approaches to academic writing instruction that dominate UK HE: English for Academic Purposes (EAP) and academic literacies. As Alicja Syska notes, the paper identifies some of the controversies, similarities and points of convergence between these two approaches to formulate pedagogical guidelines that 'get the best of both worlds'. The authors achieve this by tracing the pedagogical impact of both academic literacies and EAP and engaging with the criticisms of EAP approaches in the academic literacies model. Notably, the article extracts the most valuable elements of EAP and academic literacies, pointing out that the 'insufficiently nuanced' (p.487) criticisms of both approaches overlook their critical contributions. According to Syska's review, this argument allows the authors to demonstrate that concepts such as 'academic socialisation', 'communities of practice', and 'textual bias' are more complex than acknowledged and involve interlocking social and contextual issues that both EAP and academic literacies address in their own way. The paper thus takes on an ambitious task of developing a "'mainstream" approach to teaching writing that takes into account the complexities of academic writing and the diverse backgrounds of students at UK universities' (p.482). What is inspiring to Syska is the authors' conviction that 'rather than being two separate factions, Genre/EAP and Academic Literacies share much common ground' and 'can be brought together as complementary components in an inclusive writing pedagogy for students of all backgrounds' (p.491). The article notes the disconnect between the two factions and challenges the simple either/or categorisation of EAP versus academic literacies, instead proposing a writing pedagogy that is embedded, discipline-specific, and inclusive, one that effectively integrates writing instruction with subject knowledge. As the authors write in their conclusions, '[t]he development of academic writing could then become a truly collaborative exploration of the discipline's social practices by teachers and students' (p.492). The article offers a methodology that constructively combines the principles of EAP and academic literacies, creating potential to achieve writing support for all.

Another paper, published the same year, which explicitly sought to identify common ground and build consensus across disciplinary boundaries, is Coffin and Donohue's 'Academic Literacies and Systemic Functional Linguistics: How do they relate?' (2012). As 
lan Johnson recognises in his review, academic literacies and Systemic Functional Linguistics (SFL), are respectively strong influences on the pedagogies of Learning Development and English for Academic Purposes (EAP). SFL foregrounds analysis of written texts from the 'etic' perspective of an outsider trained in language analysis and applies this knowledge to disciplinary writing. In this way SFL offers a means to view how a language system 'is deployed through text to make meaning' (Coffin and Donohue, 2012, p.68). Pedagogically speaking, SFL proponents would emphasise designing materials to move students' (language) abilities closer to those found to be typical or 'successful' in text analysis. Coffin and Donohue explore academic literacies' contrasting roots in anthropology, leading to it valuing 'emic' views on the practices of the producers and consumers of knowledge. For academic literacies theorists, knowledge is constructed through interaction between context and text, themselves inseparable. Coffin and Donohue explain that, in direct opposition to a normative approach, the potential of academic literacies' 'critical' gaze is to render disciplinary discourses more transparent, thus open to challenge. While noting that the etic/text-based and emic/person-based starting points represent a logically incompatible difference, in line with Wingate and Tribble (2012), Coffin and Donohue suggest some cohesion would be possible if emphases were slightly shifted. They claim that academic literacies' critiques of SFL underestimate the importance of context, and how broadly 'text' is defined. Text is used in SFL to encompass concepts such as 'meaning-making resources' and 'the role of language in complex learning and knowledge building' (p.73). This expanded definition of text sits comfortably in an academic literacies perspective.

In his review of Coffin and Donohue's paper, lan Johnson examines Karl Maton's Legitimation Code Theory (LCT) (2007) and explores how it 'contribute[s] ideas by means of which complementarity [between SFL and academic literacies] can be recognized and developed ' (Coffin and Donohue, 2012, p.73). Maton's conception of LCT draws on Bernstein's work on academic disciplines (1999), which he characterised as either 'hierarchical' or 'horizontal' 'knowledge structures'. For Bernstein, horizontal structures operate in disciplines with multiple and contested viewpoints (e.g. the humanities), while hierarchical structures are more associated with seeking consensus or unified 'truth' (e.g. the sciences). Maton (2007), significantly, added the concept of 'knower structures' to recognise that in certain disciplines, the means to legitimate and reproduce norms was attained less through the knowledge base and more through displaying the 'dispositions' of 
an 'ideal knower' (p.92-93). For Maton, each discipline has one of four 'legitimation codes' based on privileging knowledge, knowers, both ('elite') or neither ('relativist'); legitimation differences partly explain the difficulties that the sciences and humanities can have in cross-communicating, and the challenge inherent in working across disciplines. A discipline's basis for legitimation is, however, open to critique and change. Maton identified the entry of more varied knowers into Higher Education from the 1960s onwards as representing an ongoing challenge to the humanities' hierarchical knower structures, themselves 'a veneer for tacit social hierarchy' (p.93). This echoes a similar point by Russell et al. (2009, p.413) who remind us of the 'transformatory' potential of academic writing while at the same time acknowledging that academics at all levels use a 'controlling, expert model' of writing, the purpose of which is to demonstrate 'the acquisition of institutional, subject or disciplinary knowledge and insiderdom' (2009, p.413). While the study of expert models of writing is in itself neutral (in that it can be used to enable transformation or to gate keep and deny access) Johnson makes explicit the connection between Maton's concerns with greater democracy and the oppositional and democratising agenda of academic literacies.

'Insider knowers', conclude Coffin and Donohue (2012), 'might be best placed to renovate a discipline' but, to do so, require 'the means to deconstruct and evaluate the discourses they work within' (p.72). Citing the work of Van Heerden, Clarence, and Bharuthram (2017), who apply LCT to feedback on written work, Johnson suggests this framework could provide a way into a discipline, rendering it more transparent to students. He identifies how this close work around text could be used to equip students with a means to expose and perhaps challenge the type of knowledge or knower valued tacitly. This confirms Coffin and Donohue's (2012) assertion of the value of challenging legitimation practices within disciplines.

The publications in this section represent an increased focus on practical application of academic literacies principles. They share a common concern with the role of language in learning at university, both as a means to explore disciplinary discourses in fine detail and as a means of honing disciplinary voice. Key questions arise about the extent to which the language of university study and academic expression is transferable across disciplinary contexts and, where differences occur, where power resides to enable, or prevent, resolution - especially for students who may work across two or more disciplines. This 
raises further difficult questions regarding the normative aspects of genres and the role of resistance to such practices as a way to develop or decolonise HE curricula - i.e. how do we teach a disciplinary form without inducting students into normative genres? Academic literacies foreground the tensions both in terms of subject positionalities but also in terms of power and the de/legitimisation of cultural practices and ways of knowing. The issue is not whether language is central to meaning making but how explicit focus on the study of form is best positioned.

What [academic literacies] seeks to explicitly avoid is the idea that students first need to learn 'the basics' and only then can be exposed to a pedagogy which leaves space for questioning and change (Lillis and Tuck 2016, p.34).

The structure of disciplinary knowledge, which is a focus of both Wingate and Tribble's and Coffin and Donohue's papers, offers scope for collaborative exploration, bringing together different communities and professional perspectives. It is an intersection that brings together academic literacies conception of literacy as a social practice with Bernstein's material focus as a sociolinguist. Legitimation code theory offers a means to

build a stronger bridge in academic literacies development practice between an understanding of the socially constructed nature of literacy practices and an understanding of the structure of knowledge from which they emerge (Clarence and McKenna, 2017, p.41).

As Johnson argues, SFL and LCT provide means to unpack disciplinary knowledge structures. An understanding of 'what it is to be academically literate across the university' (Lea and Street 1998) requires a balance of these two forms of knowledge: understanding of the structure of disciplinary knowledge as well as understanding of the norms, values, and practices that bring it to life (Clarence and McKenna, 2017, p.39). Understanding the role of disciplinary knowledge (knowledge and knower structures) would seem to be a necessary component of 'a shared ontology for academic literacies' (Lillis and Scott, 2007) and something that has potential to make significant contribution to increased cross disciplinary collaboration. 


\section{Implications for research}

In Lea and Street's original conceptualisation in the 1990s, the role of academic literacies as an approach to research (alongside a transformative, student-centred pedagogy) was always important. However, the (mis)appropriation and (mis)understanding of the term (often characterised by the use of the singular form 'academic literacy') in the early part of this century, by those interested primarily in a normative ('fix it') approach to student writing, motivated Lea and others to restate and defend the research purposes and potential of academic literacies.

Paul Harrington and Qian Zhang both contributed reviews of Lea and Street's 2006 paper 'The "academic literacies" model: Theory and applications', seeing this text as influential for their practice in learning development and EAP. As Zhang explains, Lea and Street argue that just developing academic language and understanding the language conventions used in specific disciplines are not sufficient to understand the complexity, dynamics and nuance of communication in academic contexts. Rather, they re-emphasise the role of 'social processes, including power relations among people and institutions, and social identities' (2006, p.228) in the development of literacies. Hence, epistemological issues (e.g. about 'correctness' and appropriacy), which may be taken for granted in a 'study skills' or academic socialisation model, can become subjects for investigation, critique and potential reformulation in research and pedagogy, broadening and validating student identities as participants in academic practice. Disciplinary contexts, cultures and their conventional genres also become subjects for exploration. Furthermore, wider institutional discourses and genres can be subjected to critical scrutiny via ethnographic research in ways that are helpful to the identity-formation of those from diverse or marginalised backgrounds, such as non-native speakers of English. While Harrington notes that the paper is very situated, produced from the UK in the mid-noughties as a response to the deficit model and skills agenda, he feels it remains useful despite progress made to incorporate some of the insights from academic literacies into academic practice since then. What remains true is that the transformational drive of an academic literacies perspective is yet to be widely utilised - and this paper helps to emphasise the vital role students could play in that.

Arina Cirstea reviewed a 2007 paper by Theresa Lillis and Mary Scott, 'Defining academic literacies research: Issues of epistemology, ideology and strategy', which, she points out, 
reasserts the distinctiveness of academic literacies as a field of scholarly inquiry underpinned by a focus on transformative rather than normative writing pedagogies, and a preference for critical ethnography as an approach to the study of academic writing practices. The starting point for research of this kind is locating the 'problem' of varying writing standards within institutional practices, including the absence of explicit definitions and guidelines. Rather than focusing on remedial measures, Cirstea argues that transformative practitioners should set out to define the complexity of the issue by prioritising student rather than institutional perspectives. In this respect, critical ethnography is indicated as the most appropriate tool to investigate the student writers' lived experiences while raising awareness of the power relationships involved in academic practices of 'meaning making'.

Lillis and Scott see this field as 'constituted by teacher-researchers' (2007, p.22), whose often contested and precarious positions in academic and contractual terms, imply particular needs for collective, collegial support - something most EAP and LD practitioners are very likely to agree upon. Such a situation, alongside the student focus, indicates the particular value of dialogic methodologies as part of a 'critical ethnography' practitioner research to 'critically expose issues of social justice and ethnography' (2007, p.11), which involves:

both observation of the practices surrounding the production of texts - rather than focusing solely on written texts - as well as participants' perspectives on the texts and practices. This ethnographic framing of the study of students' writing connects strongly with, and indeed gives academic credibility to, long standing practitioners' interest, in adult and higher education, in exploring and making sense of students' perspectives on academic writing, including challenging the 'taken for granted' (2007, p.11).

Although, as Harrington, Zhang and Cirstea all point out, learning development and EAP practices have taken on some aspects of the student perspective in the years since these papers were written, academic literacies remains an underutilised research and teaching framework, and its transformational power remains as potential for the development of a more inclusive, relevant, and socially just higher education systems and practices. 


\section{Implications for practice}

The issue of how to support literacy development at university in a way that aligns with the principles identified in Lea and Street's 1998 article has proved an ongoing challenge across the sector, something acknowledged by a number of writers in the field including Lea and Street (cited in Russell et al., 2009; see also Lillis, 2003; and Wingate, 2012). Some note the absence of a clear design model (Wingate, 2012), while Lillis (2008) sees academic literacies as being at the juncture of theory and practice. Lea and Street describe academic literacies as 'oppositional in nature' (Russell et al., 2009) and so what emerges from the original research paper is a set of principles, a critique of current practice, which results in a clearer conception of what academic literacies is not rather than what it is. The papers reviewed in this section were published when there was an acknowledged 'relative paucity' of literature that considered how to achieve this on a practical and structural level (Murray and Nallaya, 2016). They present examples of innovative, cross-disciplinary work, and theorise and critique these practices in the light of Lea and Street's 1998 paper. The four articles in this section are: Anna Magyar's 'Plagiarism and attribution: An academic literacies approach?' (2012), reviewed by Stephen Gow; 'On being an insider on the outside: New spaces for integrating academic literacies' by Cecilia Jacobs (2005), reviewed by Helen Hewertson; Neil Murray and Shashi Nallaya's 2016 article 'Embedding academic literacies in university programme curricula: A case study', reviewed by Craig Morley; and Neil Murray and Amanda Muller's 'Developing academic literacy through a decentralised model of English language provision' (2018), reviewed by Ide Haghi.

In her 2012 article 'Plagiarism and attribution: An academic literacies approach?', Anna Magyar reports the findings of a small qualitative study that explored international postgraduate students' understanding of plagiarism and attribution at a UK university. This paper applies an understanding of academic literacies to both the qualitative research and to the resultant materials' design of a discipline-specific online resource. Magyar identified in her analysis four dimensions to attribution: linguistic, rhetorical, epistemological, and culturally situated practice. The findings were used in the resource design, which was also informed by the complementary approaches to writing pedagogy used by Lea and Street (1998), namely skills, socialisation, and academic literacies. This resulted in four sections: 1) reasons for referencing; 2) identifying sentences that need referencing; 3) paraphrasing; 
4) structured holistic practice. What this paper makes clear is the sheer complexity of the process that students proceed through in adapting to culturally situated writing practices and the epistemology of attributable knowledge. She demonstrates how applying an academic literacies perspective offers insight as to what elements of the adaptation to study can be made explicit (through games and quizzes), the implicit process of socialisation students go through (into the language and discourse of the context/subject) and, most significantly, the textual and institutional practices (writing, reading, discussing attribution, note making), which have a deeper impact on personal and social identity. Thus, in order to not only avoid plagiarism but to understand why it is wrong in terms of authorship in the academic context, it is not simply a case of acquiring skills and following rules, but of cultural, linguistic and epistemological development, which may be highly problematic given the timescale of UK programmes. Magyar provides a lens to critically evaluate adaptation to academic practices of all students, not simply those from diverse backgrounds. She is also quite clear concerning the limitations of online tools used on a simple skills basis in quizzes and drills, demonstrating that they are neither conducive to dialogue nor support development of deeper understanding and re-orientation that is aimed for. The unpacking of the design process and the theoretically informed critique provides a welcome analysis of an arena that learning developers are increasingly working in, that of online materials' design. In doing so, this paper provides a pedagogic framework for evaluating learning resource design.

Gow in his review explicitly connects Magyar's different reasons for plagiarism with theories of epistemological development (Marton and Säljö, 1976; Baxter Magolda, 1992), transformative learning (Mezirow, 1997), and Habermas's (1987) distinction between instrumental, strategic and communicative action in the academic lifeworld (see Gow, 2018). The epistemological development referred to here indicates the complexity of decision-making that underpins the attribution process and affirms the need for a range of resources to help students learn to manage attribution in their work. While at first seemingly straightforward and familiar, Magyar's work critically reflects on the challenges of making the implicit nature of attribution in academia explicit to students from diverse backgrounds.

The remaining papers in this section are concerned specifically with who supports students to become academically literate, what spaces these staff occupy, and what 
opportunities are available to collaborate across disciplinary boundaries. In her 2005 article 'On being an insider on the outside: New spaces for integrating academic literacies', Jacobs revisits New Literacy Studies' commitment to literacy as a social practice and reexamines some fundamental questions concerning who supports students in learning to write at university. She is clear that academic literacy 'is best acquired by students when it is embedded within the contexts of particular academic disciplines' and that 'students are best inducted into the discourse communities of the various disciplines of study by modelling themselves on "insiders", others who have mastered the discourse', suggesting that disciplinary specialists are best placed to teach disciplinary writing (Jacobs, 2005, p.477). Jacobs scrutinises the expertise of different staff groups - disciplinary specialists and academic literacy practitioners/language lecturers - and critiques their current separation. She is clear that there is a need for disciplinary specialists, 'insiders' to the discourse, to share and teach their tacit unarticulated disciplinary knowledge to their students; she is also clear, however, that they may lack the skills to do this. Jacobs draws on the work of Gee (1990), making the distinction between teaching for acquisition and teaching for learning and his assertion that "meta-knowledge of the structure of a given domain of knowledge" . . . lies at the heart of teaching' (Gee, cited in Jacobs, 2005, p.480). Gee emphasises that teaching these separately "can lead to successful but "colonized" students' (Jacobs, 2005, p.478) in a way that echoes the tension in academic literacies between inducting students into the practices of a discipline while supporting them to critique it. Hewertson, in her review, explains how collaboration enables 'teaching for learning', and details how this is brought about by disciplinary specialists 'viewing the discourses of their disciplines through the eyes of a questioning [academic literacies] practitioner' (Jacobs, 2005, p.480). This collaboration allows practitioners to know 'when and how to scaffold students' growing abilities', and bring their tacit knowledge and understandings of the workings of a discourse within their disciplines into the realm of 'overt and explicit teaching' (Jacobs, 2005, p.484 and 478).

This theoretical framing is a preface to a case study based in a South African university, which explores how 20 academic literacies practitioners and disciplinary specialists integrated academic literacy into various disciplines. Reflecting on the benefits of transdisciplinary working, Jacobs maintains that the project created a new discursive space for collaboration. Hewertson draws out two key recommendations from this article: the need for a community of practice of tertiary educators that transcends the narrow 
confines of disciplinary boundaries, and the establishment of sustainable transdisciplinary discursive spaces where dialogue and collaboration can take place. This paper highlights the many challenges of collaborative cross-disciplinary working and Jacobs is clear that meeting this challenge may require a redefinition of the role of academic literacy practitioners in tertiary education.

Within the same theme of embedding, Neil Murray and Shashi Nallaya's 2016 paper presents a case study on how universities can better develop students' academic literacies through embedding support into the curricula. Craig Morley in his review explains how embedding is a natural fit for an academic literacies approach given the importance of social context and the discipline specific nature of academic skills. He points out that embedding academic literacies aligns with critiques of extra-curricular, bolt-on support (Wingate, 2006). Murray and Nallaya draw explicitly on Vygotsky's theory of learning to inform their embedding strategy and Morley notes the appropriacy and relevance of Vygotsky's ideas of scaffolding to the design of a structured curriculum that seeks to incrementally develop students' academic literacies.

This practical application of academic literacies to curriculum design was developed in response to the increased diversification of the HE student body in Australia. In this context, Murray and Nallaya emphasise we cannot 'make assumptions' about students arriving at university 'preloaded with the academic literacies they will need' (2016, p.1298); they also clearly identify the institutional responsibility to address this need. This article's case study of academic literacy provision across two subject areas presents a model that had some success in embedding academic literacies into curricula. While this model offers an example of innovative collaboration with strategic impact, Morley places it in context of an increasing number of published case studies showcasing different embedding strategies (Cairns et al., 2018; Hill and Tinker, 2018).

The authors discuss the obstacles to embedding and note the importance of establishing buy-in, particularly amongst academic staff, noting a disconnect between themselves and disciplinary academics, which had significant consequences for their project. Their example illustrates an ongoing challenge to the learning development and EAP sector, highlighting how much work is involved in articulating potential benefits of applying academic literacies principles to our work. The embedded approach adopted in this case 
study seems a particularly useful method to evidence long term impact and Morley argues that this paper makes a positive case for the larger potential impact LD/EAP can have through engaging in collaborative curriculum design. He also highlights how rethinking curricula by embedding academic literacies carefully across programmes is one important way in which HE can be made more inclusive and supportive to the diversified student body.

Embedding academic literacies may involve a centrally located disciplinary specialist working alongside subject tutors in the classroom (e.g. Jacobs, 2005) or working with disciplinary subject tutors on curriculum design (e.g. Murray and Nallaya, 2016). A third model of embedding is presented in Neil Murray and Amanda Muller's 2018 article 'Developing academic literacy through a decentralised model of English language provision', where they report on a model of academic language development provision aimed at supporting international students in a Health faculty at an Australian university. It focuses on developing the students' competency in the language skills required for their studies and professional practice, and is delivered by a member of staff employed directly by the faculty with additional courses delivered alongside the students' usual course. In this paper, Murray and Muller identify 'the lack of alignment between the language focus of gatekeeping tests and the language students need to negotiate their degree work' (2018, p.1351). They also critique the backwash that influential, international, English for General Academic Purposes tests have on the kind of academic support offered to students postenrolment. They are clear that 'one of the key weaknesses of such tests . . concerns the fact that they reflect a monolithic rather than a plurilithic view of academic literacy' (2018, p.1350). In contrast, they set out to align themselves to

an academic literacies approach to academic language development which emphasised the need to frame language ... as something specific to individual disciplines and in which learners need to become conversant if they are to gain membership of their respective communities of practice $(2018$, p.1350).

The question of who academic literacies development is targeted at remains unresolved, with some ongoing tension between staff, students, and institutional understandings of academic literacy provision and need. While academic literacies emerged in the UK in response to widening participation and growth in student numbers, and there is a research 
focus on the individual student experience, there was an original concern with institutional responsibility for literacy development. Murray and Muller's work in looking at practical applications of academic literacies reasserts this focus on the institutional, rather than personal, level of responsibility and provision.

Murray and Muller consider how to address the needs of international students who, in spite of demonstrating sufficient language to enter university in large numbers, continue to demonstrate serious problems with their academic work and progression. In some ways their case study represents an institutional response to this issue. However, targeting initiatives at international students and delivering these outside of the mainstream teaching programme has led to superficial skills-based approaches to writing development (Lea and Street, 1998, p.169) criticised as effectively apportioning blame to individual students. While the needs of home and international students are not identical, developing an understanding of academic literacies is a challenge that all HE students face. In spite of the criticisms of remedial services aimed at the needs of ever more specific, discrete student characteristics as unfeasible (Haggis, 2006, p.522), such targeted approaches remain prevalent across the sector. Murray and Muller (2018) present an example of literacy development work positioned outside of the mainstream subject teaching, which indicates an unresolved tension between institutional and pedagogic agendas and the liminal status of literacy development work.

Here academic literacies' ideological commitments to transformative education and social equity are at odds with what Turner terms 'remedial communication economy' (2018). Such an economy is both of significant strategic and financial value to Anglophone HEls and, at the same time, one that positions international students and their teachers on the margins. Murray and Muller (2018) acknowledge the dilemma of international students at the heart of this tension, as they are simultaneously welcomed in and positioned as deficient. The question is then to what extent a programme can align itself with the transformational agenda of academic literacies from a peripheral position alongside mainstream curriculum delivery, when the conventions and practices of the academy (enacted through assessment practices) have a resolutely normative orientation.

Ide Haghi's review of Murray and Muller's article identifies several advantages of decentralised academic literacies provision including promotion of more relevant teaching 
materials and generation of collaborative research with subject specialists. The role of academic literacies lecturer within a mainstream programme can also help raise awareness of student problems among other academic staff, which in turn may encourage a more sensitive and empathetic pedagogy. Undoubtedly, embedding a member of staff offers many advantages to really scrutinise the language of the discipline and examine it in use, as well as offering novel synergies with a disciplinary staff group. Haghi notes that this paper provides further evidence for the benefits of tailored academic literacy development provision, as well as detailed and practical guidelines on how decentralised models of such provision can be implemented. However, this model is still a long way from fully embedded academic literacies delivered routinely to all students as part of their course. It suggests a need to examine an alternative fully embedded subject specific exploration that acknowledges and addresses the literacy development needs of the whole student body.

The papers in this section all address the practical challenge of teaching in a way that aligns with academic literacies principles (Lea and Street, 1998). Taken together it is possible to garner if not a design frame, then a few principles for practice aligned to academic literacies:

\section{Mainstreamed and embedded}

Although academic literacies emerged from analysis of widening participation, the centrality of literacy development to higher education and rejection of deficit frames suggest that learning and literacy development are relevant to all students and subjects (Lea, 2016, p.89). Similarly, separation of development work according to whether English is a student's first, second, additional, or foreign language are distinctions that have been actively challenged by academic literacies practitioners (Lillis and Tuck, 2016, p.39).

As Lillis and Tuck put it, '[a] social practices perspective entails a view of writing as inseparable from context' (2016, p.35). Analysis of this context has led to acknowledging the need to work at a level of disciplinary specificity and to recognise that students are increasingly expected to fluently manage a diverse set of literacy practices across a range of media and modes. This suggests the need to resist the common practice of managerial separation of language, and learning developer from subject tutor. 


\section{Critical and transformative stance}

A common theme throughout academic literacies writing is the foregrounding of issues of power and authority evident in language and learning. In practical terms this implies a need to go further than clarifying disciplinary expectations and to engage students in critique, acknowledging the tension between 'being explicit about norms and conventions of disciplines and opening up curriculum spaces for these to be contested' (Jacobs, 2013, p.133). This reflexive critical stance extends to our institutional and disciplinary norms.

Researchers and practitioners in academic literacies tradition assert a commitment to critical intellectual value and purpose of university (Lea, 2016) and emphasise the need for transformation in pedagogy and a transformative orientation to language and academic production (Lillis and Tuck, 2016, p.39). This ideological orientation implies a particular stance towards students who are drawn into this space as participants, legitimating students as knowledge producers as well as 'the resources for meaning making' that the students themselves bring to the university (see Lillis and Scott, 2007, p.19).

\section{Space for diverse knowledge making practices}

There has been an expansion of conception of literacy from a focus in 1998 on learning to write at university to now include a diverse range of textual and digital knowledge making practices across the university.

Re-positioning of the student body and rejection of normative pedagogy have led to calls to establish 'richer forms of engagement' (Haggis 2006, p.522). At the same time, Lea reflects on 'whether the written word . . can ever engage fully with the notion of student writing as meaning making without the dialogic, exploratory and critical possibilities of student-teacher interactions' (Lea, 2016, p.91). This suggests that rather than searching for a definitive design frame that can be institutionally enacted, there is a need to reconfigure curricular spaces for formative, dialogic learning to invite students to explore their subjects and take risks with their learning.

While we continue to search for alternative ways to use writing and literacies to 'resist deeply entrenched attitudes about writing, and about students and disciplines' (Russell, 
2009, p.396), we must find new ways to cross rigid disciplinary divides, create novel spaces for learning, and new hybrid staff roles. As Morley suggests, there are opportunities here for learning developers and applied linguists to have strategic impact at scale beyond their immediate teaching responsibilities. Undoubtedly, taking full advantage of these opportunities relies on our ability to collaborate and persuasively communicate the successes and opportunities that an academic literacies approach can afford.

\section{Conclusion}

Lea and Street's 1998 paper was genuinely ground-breaking and has had significant impact on HE research, pedagogy, and policymaking in many countries. Its popularity and influence among our professional communities is evident in the profusion of research and literature it has prompted and the number of citations it still receives. The range of articles referred to above, selected by colleagues from our aligned professional communities of EAP and learning development, demonstrates the breadth and persistence of interest in academic literacies, not least because research in this field raised questions about the nature of literacy at university in a way that rejected the deficit framing of students. If, twenty years ago, issues of literacy at university were marginalised and institutionally invisible (Street, 1999; Turner, 2018), now the debate about how best to work with a range of students characterised by cultural and linguistic diversity is lively and enriched. There is a substantial body of research and literature on academic literacies for practitioners to draw upon, which offers validation of the centrality of language practices in the higher education curriculum, and its relationships with the roles, power and opportunities for achievement available to participants. The importance of language and learning development - and, by implication, the work of practitioners in our communities - is thereby firmly established.

\section{Generating research}

Academic literacies approaches have offered a new perspective for the study of $\mathrm{HE}$ classroom practice, suggesting a focus on issues of roles, voices, and subject positions of staff and students. They also indicate moving beyond an approach to text that assumes its transparency and thereby point to research into the culturally situated complexities of learning to communicate at university. Understanding the situated nature of literacy implies 
a need to analyse the quality of disciplinary discourses and conceptions of graduate-level attainment, including the need for code-switching across subject, genre, and mode (Lea and Street, 1998). As the articles analysed in this review demonstrate, there is a recurrent concern with drawing out issues of power, both at the level of individual interaction and structurally at an institutional level, examining the gaps between discourses and agendas (Russell et al., 2009). The stress on an ethnographic focus on individuals and on practices in an academic literacies approach offers a framework for research and the development of pedagogy that is well-suited to meeting the challenges facing early twenty-first century HE practitioners. Such work implies, for example, helping students grapple with tacit expectations in terms of their learning practices, identity and identification (see Gourlay, 2009; Burgess and Ivanic, 2010; French, 2016). The proliferation of topics and themes for research generated by academic literacies approaches is well illustrated by the literature reviewed in this paper. Much of it can be traced back to interest in pursuing the assertion in Lea and Street's 1998 paper that academic writing is both complex and contested in respect of the gaps between the discourses of teaching, learning and institutional communications and students' lived experience.

\section{Contested Terminology}

One consequence of the popularity of the term 'academic literacies' has been the 'considerable fluidity and at times confusion in meanings attached to the use of the phrase' (Lillis and Scott, 2007, p.6). Furthermore, Lillis and Scott note 'the ways in which it is adopted and co-opted for use in many settings, often with a range of meanings sometimes confusing and contradictory and sometimes strategic' (p.6). This diversity of understandings and interpretations suggests that, as a sector, we are still exploring what 'academic literacies' can mean in practice.

The popularity of the term and the diverse manner in which it was used led key authors (Lea and Street, 2006; Lillis and Scott, 2007; Lea, 2016,) to re-assert some of its key principles: its critical stance and the ambition and scale of its perspective, which act as a counterpoint to the focus on individual practices and small-scale investigations. These distinctions are crucial to understanding the critiques of normative practices and academic literacies' affinity with critical EAP and the traditions and approaches of critical linguistics (Freire, 1972; Pennycook, 2010). 
Here we reach a juncture between different practitioner groups who support writing development and learning at university, and who have developed distinct practical responses to the criticality of academic literacies. Faced with increasing numbers of international students accepted onto relatively short courses in Anglophone contexts, practitioners experience considerable pressures to adopt normative approaches and induct students to meet Anglophone norms. In contrast, for staff supporting home students, the critical oppositionality of academic literacies challenges the liminal status of students who are marginalised by mainstream higher education while being welcomed into it. The question is to what extent such criticality is central to an education that aims to be transformative.

\section{Academic literacies approaches}

The typology of approaches to writing development (skills, socialisation, and academic literacies) first outlined by Lea and Street (1998) received much attention from our community of practitioners. Lea explains that in their original formulation 'academic socialisation was concerned with the acculturation of students into disciplinary academic discourse and culture, ... [ [whereas] academic literacies focus[ed] on institutional practices, change and power and institutions as sites of contested meaning making' (2016, p.90). Lea and Street (1998) presented academic literacies as building on skills and socialisation approaches to writing and learning development rather than in opposition to them. However, the exact nature of the relationship between approaches has proved difficult to define, both in theory and in practice. If the relationship between these approaches is not one of linear progression then this raises many practical questions concerning the delivery of, and the relationship between, these different approaches to learning, and whether current organisational arrangements for working with students and staff across the university are fit for purpose (Jacobs, 2005; Wingate, 2015).

The intersection of textually focused approaches and academic literacies is especially sharp when considering the needs of home and international students. The challenge of how to enable students to critique the work of a discipline they seek membership of is particularly pertinent for international students (see Wingate and Tribble, 2012; Wingate, 2015; Murray and Nallaya, 2016; Murray and Muller, 2018). This confirms the complexity 
of the precise nature of the relation of language to learning. While there is a desire to identify commonalities and areas of intersection between EAP and academic literacies (Wingate and Tribble, 2012), if the practical focus is on providing students with the tools to deconstruct and manage their own disciplinary journey, the question remains at what point are issues of power and identity addressed. Lillis and Scott (2007) crucially distinguish between 'normative' and 'transformative' approaches, analysing key tropes and metaphors used to describe learning. They identify communities of practice, apprenticeships, socialisation, scaffolding, novice and experts as terms drawn from sociocultural theory and signalling a researcher's normative interest. In contrast, they note that explicit discussions of power and authority, the use of notions of dialogism, hybridity, and intertextuality indicate a position in which conventions are viewed as contested and meaning making as a site of struggle (Lillis and Scott, 2007, p.13). Lea warns against simple labels, suggesting that 'the distinction we made between academic socialisation and academic literacies is too crude, particularly when the former becomes explicitly associated with a normative approach' (Lea, 2016, p.91). The value in distinguishing between normative and transformative approaches is in its explication of theory underpinning practices and the way it raises awareness and encourages critique of our pedagogic habits.

\section{Modality}

The digitalisation of university study has been acknowledged as '[p]robably one of the most significant changes to the higher education landscape and to the relationship between students and university teachers' (Lea, 2016, p.94). This shift in mode of delivery continues to have huge impact on the emerging textual and multimodal practices of university study (Goodfellow, 2005; Archer, 2006; Lillis and Tuck, 2016). In applying academic literacies theory to online resource design, Magyar (2012) reveals how teaching in an online blended environment requires a more nuanced understanding of social and relational implications of teaching resources, and how different designs position learners in different ways. Similarly, Lea (2016) and Lillis and Tuck (2016) note that, when using a written channel, the substantive content is reified, meaning that however discursively framed or intended, there is a real challenge of maintaining a transformative stance when information is written down. Given the ubiquity of online learning environments at UK universities, an understanding of how academic literacies are constructed in online environments is vital for learning developers and EAP tutors. This suggests a need to be 
able to work across modalities and apply theoretical and epistemological critiques to scrutinise emerging textual and multimodal practices, including our own as developers and teachers.

\section{Future perspectives}

Since 1998, academic literacies perspectives have increasingly influenced researchers' and practitioners' attempts to 'engage with complex issues surrounding . . . student academic writing, in contrast to the often impoverished perspective on language and literacy that is trumpeted in official and public discourses' (Lillis and Scott, 2007, p.21). The literature referred to in this review demonstrates the rich potential for further research, and the development of practice, offered by academic literacies perspectives. The sizeable response to our call for reviews (over 20 submissions) for this literature review is evidence of the numbers of practitioner researchers still inspired by Lea and Street's 1998 paper and for whom the term 'academic literacies' is relevant to their professional thinking and identity. Their ideas will continue to stimulate critical questioning of dominant discourses and inspire resistance to the 'relentless marketisation of the sector' and 'redefinition of the university for its commercial and transfer utility, as opposed to its intellectual or critical value' (Lea, 2016, p.97). The drive to teach and develop academic literacies that are appropriate, inclusive and empowering, as well as academically rigorous, alongside our students, is a motive shared among the professional learning development, writing development, and EAP communities. Sharing our ideas through projects such as this literature review is an act of collaboration and cross-fertilisation that can encourage us to be ambitious for the future; to co-operate further to promote a wider conception of what counts as appropriate resources for academic meaning making; and to engage our students in negotiation and dialogue to explore what is possible, rather than merely what is acceptable (Lillis and Tuck, 2016).

\section{References}

Archer, A. (2006) 'A multimodal approach to academic literacy practices: problematising the visual/verbal divide', Language and Education, 20(6), pp.449-462. Available at: https://doi.org/10.2167/le677.0 (Accessed: 7 October 2019). 
Ashworth, M., Bloxham, S. and Pearce, L. (2010) 'Examining the tension between academic standards and inclusion for disabled students: the impact on marking of individual academics' frameworks for assessment', Studies in Higher Education, 35(2), pp.209-223. Available at: DOI: 10.1080/03075070903062864 (Accessed: 7 October 2019).

Baxter Magolda, M.B. (1992) 'Students' epistemologies and academic experiences: implications for pedagogy', The Review of Higher Education, 15(3), pp.265-287. Available at: https://doi.org/10.1353/rhe.1992.0013 (Accessed: 7 October 2019).

Bazerman, C., Bonini, A. and Figueiredo, D. (eds.) (2009) Genre in a changing world: perspectives on writing. Colorado: WAC Clearinghouse/Parlor Press.

Bernstein, B. (1999) 'Vertical and horizontal discourse: an essay', British Journal of Sociology of Education, 20(2), pp.157-173. Available at: https://doi.org/10.1080/01425699995380 (Accessed: 20 September 2019).

Bernstein, B. (2000) Pedagogy, symbolic control and identity. $2^{\text {nd }}$ edn. Oxford: Rowman and Littlefield Publishers.

Biggs, J. and Tang, C. (2011) Teaching for quality learning at university. UK: McGraw-Hill Education.

Burgess, A. and Ivanič, R. (2010) 'Writing and being written: issues of identity across timescales', Written Communication, 27(2), pp.228-255. Available at: https://journals.sagepub.com/doi/10.1177/0741088310363447 (Accessed: 7 October 2019).

Cairns J., Hervey, T. and Johnson, O. (2018) Neither "bolt-on" nor "built-in": benefits and challenges of developing an integrated skills curriculum through a partnership model', Journal of Learning Development in Higher Education, 13 (April). Available at: https://journal.aldinhe.ac.uk/index.php/jldhe/article/view/435 (Accessed: 7 October 2019). 
Cameron, H. and Billington, T. (2015) 'The discursive construction of dyslexia by students in higher education as a moral and intellectual good', Disability \& Society, 30(8), pp.1225-1240. Available at: https://doi.org/10.1080/09687599.2015.1083846 (Accessed: 7 October 2019).

Christie, F. and Martin, J. (eds.) (2007) Language, knowledge and pedagogy: functional linguistic and sociological perspectives. London: Continuum.

Clarence, S. and Mckenna, S. (2017) 'Developing academic literacies through understanding the nature of disciplinary knowledge', London Review of Education. 15, pp.38-49. DOI: 10.18546/LRE.15.1.04. (Accessed: 7 October 2019).

Coffin, C. and Donohue, J. (2012) 'Academic literacies and systemic functional linguistics: how do they relate?' Journal of English for Academic Purposes, 11, pp.64-75. Available at: https://doi.org/10.1016/.j.jeap.2011.11.004 (Accessed: 20 September 2019).

Disabled Students' Allowance Consultation: Equality Analysis [DSAC] (2015) Department for Business, Innovation and Skills (BIS-HEFCE). Available at: https://assets.publishing.service.gov.uk/government/uploads/system/uploads/attach ment data/file/481527/bis-15-658-disabled-students-allowances-equalityanalysis.pdf (Accessed: 19 August 2019).

Eurydice (The Education, Audiovisual and Culture Executive Agency) (2014) 'Modernisation of higher education in Europe 2014, Access, retention and employability'. Available at: https://publications.europa.eu/en/publication-detail//publication/59560dcc-a3c3-11e5-b528-01aa75ed71a1/language-en (Accessed: 10 October 2019).

Fairclough, N. (1992) Discourse and social change. Cambridge: Polity.

Freire, P. (1972). Pedagogy of the oppressed. New York: Herder and Herder. 
French, A. (2016) "Fail better": reconsidering the role of struggle and failure in academic writing development in higher education', Innovations in Education and Teaching International, 55(4), pp.408-416. Available at:

DOI: 10.1080/14703297.2016.1251848 (Accessed: 10 October 2019).

Fuller, M., Healey, M., Bradley, A. and Hall, T. (2004) 'Barriers to learning: a systematic study of the experience of disabled students in one university', Studies in Higher Education, 29(3), pp. 303-318. DOI: 10.1080/03075070410001682592. (Accessed: 10 October 2019)

Gee, J. P. (1990) Social linguistics and literacies: ideology in discourses. London: Falmer.

Goodfellow, R. (2005) 'Academic literacies and e-learning: a critical approach to writing in the online university', International Journal of Educational Research, 43(7-8), pp.481-494. Available at: http://oro.open.ac.uk/7847/ (Accessed: 10 October 2019).

Gourlay, L. (2009) 'Threshold practices: becoming a student through academic literacies', London Review of Education, 7(2), pp.181-192. Available at: DOl: 10.1080/14748460903003626 (Accessed: 10 October 2019).

Gow, S. (2018) Epistemological obstacles to academic integrity: mainland Chinese students' perceptions of studying in the UK through the Habermasian Lens. PhD thesis, University of York. Available at: http://etheses.whiterose.ac.uk/24119/ (Accessed: 23 October 2019).

Habermas, J. (1987) The theory of communicative action. Boston: Beacon Press.

Haggis, T. (2006) 'Pedagogies for diversity: retaining critical challenge amidst fears of "dumbing down"', Studies in Higher Education, 31(5), pp.521-535. Available at: DOI: 10.1080/03075070600922709 (Accessed: 10 October 2019).

Harris, A. (2014) The creative turn: toward a new aesthetic imaginary. Rotterdam: Sense. 
Hill, P. and Tinker, A. (2018) 'Making the second year count: embedding learning development in a progressive student journey', Journal of Learning Development in Higher Education, Special Edition: ALDinHE Conference 2018 (October). Available at: http://journal.aldinhe.ac.uk/index.php/jldhe/article/view/482 (Accessed: 10 October 2019).

Hilsdon, J. (2011) 'What is learning development?' in Hartley, P., Hilsdon, J. Keenan, C. Sinfield, S. and Verity, M. (eds.) Learning development in higher education. London: Palgrave Macmillan, pp.13-27.

Ivanič, R. (1998) Writing and identity. Amsterdam: John Benjamin's Publishing Company.

Jacobs, C. (2005) 'On being an insider on the outside: new spaces for integrating academic literacies', Teaching in Higher Education, 10(4), pp.475-487. Available at: DOI: 10.1080/13562510500239091 (Accessed: 10 October 2019).

Jacobs, C. (2013) 'Academic literacies and the question of knowledge', Journal for Language Teaching, 47(2), pp. 127-139. Available at: http://dx.doi.org/10.4314/jlt.v47i2.7 (Accessed: 10 October 2019).

Kinder, J. and Elander, J. (2012) 'Dyslexia, authorial identity, and approaches to learning and writing: a mixed methods study', British Journal of Educational Psychology, 82(2), pp.289-307. Available at: DOI: 10.1111/j.2044-8279.2011.02026.x (Accessed: 10 October 2019).

Kress, G. and Van Leeuwen, T. (2001) Multimodal discourse: The modes and media of contemporary communication. London: Arnold.

Lave, J. and Wenger, E. (1991) Situated learning: legitimate peripheral participation. Cambridge: Cambridge University Press.

Lea, J. (2015) 'The landscape of higher education', in Lea, J. (ed.) Enhancing learning and teaching in higher education: engaging with the dimensions of practice. Maidenhead, United Kingdom: Open University Press. 
Lea, M. (2016) 'Academic literacies: looking back in order to look forward', Critical Studies in Teaching \& Learning, 4(2), pp.88-101. Available at: https://www.ajol.info/index.php/cristal/article/view/149790 (Accessed: 10 October 2019).

Lea, M. and Street, B. (1998) 'Student writing in higher education: an academic literacies approach', Studies in higher education, 23 (2), pp.157-172. Available at: DOI: 10.1080/03075079812331380364 (Accessed: 10 October 2019).

Lea, M. and Street, B. (2006) 'The "academic literacies" model: Theory and applications', Theory into Practice, 45(4) pp.368-377. Available at: http://oro.open.ac.uk/21057/ (Accessed: 10 October 2019).

Lillis, T. (2003) 'Student Writing as 'Academic Literacies': Drawing on Bakhtin to Move from Critique to Design', Language and Education, 17(3), pp.192 -207. Available at: http://oro.open.ac.uk/6379/ (Accessed: 10 October 2019).

Lillis, T. (2008) 'Ethnography as method, methodology, and "deep theorizing": closing the gap between text and context in academic writing research', Written Communication, 25(3), pp.353-388. Available at: http://oro.open.ac.uk/17069/ (Accessed: 10 October 2019).

Lillis, T. and Scott, M. (2007) 'Defining academic literacies research: issues of epistemology, ideology and strategy', Journal of Applied Linguistics, 4(1) pp.5-32. Available at: http://oro.open.ac.uk/17057/ (Accessed: 10 October 2019).

Lillis, T. and Tuck, J. (2016) 'Academic literacies: a critical lens on writing and reading in the academy', in Hyland, K. and Shaw, P. (eds.) The Routledge handbook of English for Academic Purposes. Routledge Handbooks: Routledge, pp.30-43. Available at: https://oro.open.ac.uk/44768/3/academicliteracies\%20\%20lillis\%20\%26\%20tuck.pdf (Accessed: 10 October 2019). 
Magyar, A. E. (2012) 'Plagiarism and attribution: an academic literacies approach?' Journal of Learning Development in Higher Education, No. 4 (2012). Available at: https://journal.aldinhe.ac.uk/index.php/jldhe/article/view/141 (Accessed: 10 October 2019).

Mann, S. J. (2001) 'Alternative perspectives on the student experience: alienation and engagement', Studies in Higher Education, 26(1), pp.7-19. Available at: DOI: 10.1080/03075070020030689 (Accessed: 10 October 2019).

Marton, F. and Säljö, R. (1976) 'On qualitative differences in learning: outcome and process', The British Journal of Educational Psychology, 46 (1), pp.4-11.

Maton, K. (2007) 'Knowledge-knower structures in intellectual and educational fields', in Christie, F. and Martin, J. (eds.) Language, Knowledge and Pedagogy: Functional linguistic and sociological perspectives. London:Continuum, pp.87-108. Available at: https://ro.uow.edu.au/cgi/viewcontent.cgi? referer=https://www.google.com/\&httpsre dir=1\&article=1915\&context=sspapers (Accessed: 10 October 2019).

Maton, K. (2017) 'Making waves together: How LCT can help crack the codes of education', BALEAP 2017 Conference, University of Bristol, Bristol 7-9 April. Available at: https://www.baleap.org/wp-content/uploads/2016/04/Plenary-2-MatonSlides.pdf (Accessed: 20 September 2019).

McKenna, C. and Hughes, J. (2013) 'Values, digital texts, and open practices-a changing scholarly landscape in higher education', in Goodfellow, R. and Lea, M. (eds.), Literacy in the digital university: critical perspectives on learning, scholarship and technology. London/New York: Routledge, pp.15-26.

Mezirow, J. (1997) 'Transformative learning: theory to practice', New Directions for Adult and Continuing Education, 74, pp.5-12.

Morken, F. and Helland, T. (2013) 'Writing in dyslexia: product and process', Dyslexia, 19 (3), pp.131-148. Available at: DOI: 10.1002/dys.1455 (Accessed: 10 October 2019). 
Mortimore, T. and Crozier, W. R. (2006) 'Dyslexia and difficulties with study skills in higher education', Studies in Higher Education, 31 (2), pp.235-251. Available at: DOI: 10.1080/03075070600572173 (Accessed: 10 October 2019).

Murray, N. and Muller, A. (2018) 'Developing academic literacy through a decentralised model of English language provision', Journal of Further and Higher Education, 43(10), pp.1348-1362. Available at: DOI: 10.1080/0309877X.2018.1483015 (Accessed: 10 October 2019).

Murray, N. and Nallaya, S. (2016) 'Embedding academic literacies in university programme curricula: a case study', Studies in Higher Education, 41(7), pp.1296- 312. Available at: DOI: 10.1080/03075079.2014.981150 (Accessed: 10 October 2019).

Office of Fair Access UK [OFA] (2017) Understanding a Whole Institution Approach to Widening Participation. Available at: https://www.offa.org.uk/egp/whole-institutionapproach (Accessed: 19 August 2019).

Pennycook, A. (2010) Critical applied inguistics: a critical introduction. London: Routledge.

Pino, M. and Mortari, L. (2014) 'The inclusion of students with dyslexia in higher education: A systematic review using narrative synthesis', Dyslexia, 20(4), pp.346-369. Available at: DOI: 10.1002/dys.1484 (Accessed: 10 October 2019).

Riddell, S., Weedon, E., Fuller, M., Healey, M., Hurst, A., Kelly, K. and Piggott, L. (2007) 'Managerialism and equalities: tensions within widening access policy and practice for disabled students in UK universities', Higher Education, 54(4), pp.615-628. Available at: doi.org/10.1007/s10734-006-9014-8 (Accessed: 10 October 2019).

Russell, D. R., Lea, M., Parker, J., Street, B. and Donahue, T. (2009) 'Exploring notions of genre in 'academic literacies' and 'writing across the curriculum': approaches across countries and contexts', in Bazerman, C., Bonini, A. and Figueiredo, D. (eds.) Genre in a Changing World Perspectives on Writing. Colorado: WAC Clearinghouse/Parlor Press, pp.395-423. 
Scalone, P. and Street, B. (2006) 'An academic language development programme (widening participation)', in Leung, C. and Jenkins, J. (eds.) Reconfiguring Europe: the contribution of applied linguistics. London: Equinox, pp.123-37.

Scott, P. (1995) The meanings of mass higher education. Buckingham, United Kingdom: Society for Research into Higher Education.

Shaw, J. (2009) 'The diversity paradox: does student diversity enhance or challenge excellence?' Journal of Further and Higher Education, 33(4), pp.321-332. Available at: DOI: 10.1080/03098770903266018 (Accessed: 10 October 2019).

Smith, R. (2007) 'An overview of research on student support: helping students to achieve or achieving institutional targets? Nurture or de-nature?' Teaching in Higher Education, 12(5-6), pp.683-695. Available at: https://wlv.openrepository.com/bitstream/handle/2436/7588/Helping\%20Students\% 20To\%20Achieve.pdf?sequence=1 (Accessed: 10 October 2019).

Street, B. (1984) Literacy in theory and practice. Cambridge: Cambridge University Press.

Street, B. (1999) 'Academic Literacies' in Jones, C., Street, B. (eds.) Students writing in the university: cultural and epistemological issues. Amsterdam and Philadelphia: John Benjamins Publishing Company, pp.193-227.

Tribble, C. and Wingate, U. (2013) 'From text to corpus: a genre based approach to academic literacy instruction', System, 41(2), pp.307-321. Available at : https://doi.org/10.1016/j.system.2013.03.001 (Accessed: 10 October 2019).

Turner, J. (2018) On writtenness the cultural politics of academic writing. London: Bloomsbury.

van Heerden, M., Clarence, S. and Bharuthram, S. (2017) 'What lies beneath: exploring the deeper purposes of feedback on student writing through considering disciplinary knowledge and knowers'. Assessment and Evaluation in Higher Education, 42(6), 
pp.967-977. Available at: DOI: 10.1080/02602938.2016.1212985 (Accessed: 10 October 2019).

Vygotsky, L. (1978) Mind in society. London: Harvard University Press.

Wenger, E. (1998) 'Communities of practice: learning as a social system', Systems Thinker, 9(5), pp.2-3. Available at: https://thesystemsthinker.com/communities-ofpractice-learning-as-a-social-system/ (Accessed: 10 October 2019).

Wingate, U. (2006) 'Doing away with "study skills"', Teaching in Higher Education, 11(4), pp.457-469. Available at: DOI: 10.1080/13562510600874268 (Accessed: 10 October 2019).

Wingate, U. (2012) ' Using academic literacies and genre-based models for academic writing instruction: a 'literacy' journey', Journal of English for Academic Purposes, 11(1) pp.26-37. Available at: DOI: 10.1016/j.jeap.2011.11.006 (Accessed: 10 October 2019).

Wingate, U. (2015) Academic literacy and student diversity: the case for inclusive practice. Multilingual Matters: Bristol.

Wingate, U. and Tribble, C. (2012) 'The best of both worlds? Towards an English for Academic Purposes/academic literacies writing pedagogy', Studies in Higher Education, 37(4), pp.481-495. Available at: DOI: 10.1080/03075079.2010.525630 (Accessed: 10 October 2019).

Wortham, S. (2003) 'Curriculum as a resource for the development of social identity', Sociology of Education, 76, pp.228-246. Available at: https://repository.upenn.edu/gse pubs/210/ (Accessed: 10 October 2019). 


\section{Author details}

John Hilsdon is the former Head of Learning Support and Wellbeing at the University of Plymouth, UK. He is a National Teaching Fellow and completed a doctorate examining the significance of Learning Development in 2018.

Cathy Malone is an Education Developer at Sheffield Hallam University with an interest in supporting students in learning to write and writing to learn in HE.

Alicja Syska is a hybrid academic working across Learning Development and History at the University of Plymouth, UK.

\section{Contributors}

We would like to acknowledge and thank the following colleagues who contributed individual reviews to this community-sourced literature review:

Brittany Amell, Carleton University, Canada

Arina Cirstea, De Montfort University, Leicester

Jessica Garska, Trinity College Dublin

Stephen Gow, University of York

Ide Haghi, University of Bristol

Aileen Hanrahan, Independent Researcher

Paul Harrington, University of Plymouth

Helen Hewertson, University of Central Lancashire

John Hilsdon, University of Plymouth

Christina Howell-Richardson, Birkbeck College, University of London

Ian Johnson, University of Portsmouth

Peter Levrai, University of Turku

Cathy Malone, Sheffield Hallam University

Craig Morley, University of Manchester

Louise Stringer, University of York

Alicja Syska, University of Plymouth

Qian Zhang, University of Northampton 